\title{
ANALISIS KEMAMPUAN REPRESENTASI GAMBAR DAN MATEMATIS MATERI GERAK LURUS PADA SISWA SMA DI BONDOWOSO
}

\author{
${ }^{1)}$ Adinda Della W.A, ${ }^{1)}$ I Ketut Mahardika, ${ }^{1)}$ Singgih Bektiarso \\ ${ }^{1)}$ Program Studi Pendidikan Fisika FKIP Universitas Jember \\ E-mail: adindadella46@gmail.com
}

\begin{abstract}
Multirepresentation is a learning approach that provides information in various forms to make it easier for students to understand learning materials in the form of diverse representation. This research aimed to analyze the ability of image representation and mathematical representation of students. Type of this research was descriptive research. Respondents in this research were 3 schools in Bondowoso district, namely SMAN 1 TENGGARANG, SMAN 1 TAPEN, and SMAN 3 BONDOWOSO. The data collection method in this research used tests, interviews, and documentation. The test instrument consists of 5 questions containing aspects of image and mathematical representation. The test results are data on the ability to represent images and mathematically as well as classification of student ability categories presented in percentage form. The multirepresentation capability category was divided into 4 categories, namely very good, good, enough, less, and very less. Based on the data obtained, it was known that the highest ability is in the representation of images with the average score of students in 3 different schools of $95.2 \%$ in the category of excellent. The average score of mathematical representation capability is $87.3 \%$ with a very good category.
\end{abstract}

Key word: Physics, Concepts, Multirepresentation Capabilities

\section{PENDAHULUAN}

Sains merupakan serumpun ilmu yang mempelajari dan memberikan penjelasan di tiap-tiap fenomena alam di sekitar. Fisika merupakan pembelajaran yang mempelajari fenomena alam yang berasal dari besaran fisis (Doyan dkk, 2018:36). Dalam pembelajarannya fisika menjelaskan materi pembelajaran dengan menggunakan konsep serta teori. Materi pembelajaran fisika terdiri dari banyak konsep yang harus dipahami oleh siswa. Konsep yang terdapat dalam pembelajaran fisika bersifat abstrak. Menurut Ismet (dalam Najib dkk, 2020) mengatakan bahwa konsep-konsep yang terdapat dalam pembelajaran fisika berupa suatu simbol abstrak. Menurut Harahap (2017:150) siswa diharuskan lebih memahami konsep dari hanya menghafalkan rumus matematis saja.

Pengetahuan konseptual yang abstrak dalam pembelajaran fisika mengakibatkan siswa mengalami kesulitan untuk menguasai konsep yang diajarkan. Hal ini disebabkan karena siswa hanya menerima pembelajaran melalui satu jenis representasi saja. Hal ini selaras dengan pendapat Selamet dkk (2018:147) yang mengatakan bahwa siswa terkendala untuk memahami konsep yang diajarkan karena dalam proses pembelajarannya guru hanya terfokus pada 
satu representasi saja. Pembelajaran fisika hanya berpusat menjelaskan persamaan matematis, tanpa diikuti dengan pemahaman konsep siswa (Alexandru, 2017:1). Memahami konsep fisika mengharuskan siswa untuk menguasai lebih dari satu kemampuan representasi. Hal ini dimaksudkan agar siswa lebih mudah dalam menerima materi yang diajarkan.

Multirepresentasi dianggap mampu mengatasi kendala yang dialami oleh siswa. Menurut Mahardika (dalam Dudeliany dkk, 2021) menyatakan bahwa multirepresentasi merupakan cara penyampaian konsep yang menggunakan beragam cara serta bentuk yang berupa verbal, matematika, gambar, dan grafik. Pendekatan multirepresentasi dapat mempermudah siswa dalam proses memahami konsep yang diajarkan. Menguasai konsep fisika bisa dilakukan dengan membuat mental model dengan suatu cara representasi (Mahardika, 2016). Pendekatan multirepresentasi memberi pengaruh baik terhadap kemampuan kognitif siswa dari kognitif rendah hingga kognitif di tingkat yang lebih tinggi.

Representasi yang jarang digunakan dalam kegiatan pembelajaran adalah representasi gambar. Hal ini sesuai dengan pernyataan Monica dalam (Hadiyanti dkk, 2019:119) guru jarang menerapkan representasi grafik, gambar, dan diagram dalam pembelajaran guna menyampaikan suatu konsep. Representasi gambar dikatakan mampu membantu siswa untuk memberikan penjelasan detail tentang permasalahan fisika yang sedang dipelajari. Representasi gambar adalah suatu kemampuan mendefinisikan suatu permasalahan matematis ke dalam bentuk gambar (Kartini, 2009:366). Representasi gambar sering digunakan guru untuk memberikan penjelasan kepada siswa dengan cara yang lebih mendetail sehingga diharapkan memberi pemahaman yang lebih kuat. menurut Yusup (dalam Apriliyani,
2019) upaya menguasai konsep fisika akan lebih mudah jika direpresentasikan pada bentuk gambar. Pembelajaran fisika dengan menggunakan representasi gambar mampu menggambarkan konsep abstrak yang terkandung pada materi fisika yang sedang dipelajari.

Representasi yang sering digunakan dalam kegiatan pembelajaran adalah representasi matematis. Menurut Yuniarti (2016) mengatakan bahwa sebagai kemampuan dasar yang harus dimiliki siswa maka kemampuan representasi matematis harus selalu digunakan pada proses pembelajaran. Representasi matematis merupakan representasi yang sering ditekankan guru dalam memberikan materi pembelajaran pada siswa. Menurut Lestari (dalam Mahendra, 2019:287) representasi matematis adalah kemampuan menyajikan ulang konsep notasi, simbol, tabel, gambar, diagram, persamaan matematis ke dalam bentuk lain. Akan tetapi, jika pembelajaran hanya menggunakan representasi matematis saja maka pembelajaran yang berlangsung tidak akan berjalan dengan maksimal. Hal ini selaras dengan penelitian Arifah dkk (2020) yaitu siswa yang berkemampuan tinggi dapat menggunakan seluruh kemampuan representasi dalam proses pembelajaran. Representasi matematis adalah kemampuan mengemukakan gagasan matematis yang berfungsi sebagai alat untuk menemukan solusi permasalahan matematis yang dihadapi (Mahendra dkk, 2019:287). Pembelajaran fisika akan lebih mudah dipahami apabila konsep yang terkandung didalamnya disajikan ke dalam bentuk matematis. Representasi matematis sangat penting untuk dikuasai oleh siswa untuk menentukan keberhasilan belajar siswa.

Berdasarkan pentingnya kemampuan representasi gambar dan representasi matematis pada latar belakang maka analisis kemampuan representasi gambar dan representasi matematis harus dilakukan. 
Sehingga tujuan penelitian ini membahas tentang "Analisis Kemampuan Representasi Gambar dan Matematis Materi Gerak Lurus pada Siswa SMA di Bondowoso".

\section{METODE}

Jenis penelitian ini adalah penelitian deskriptif. Tempat penelitian ditentukan dengan menggunakan metode purposive sampling area yaitu tempat yang sengaja dipilih berdasarkan beberapa pertimbangan seperti berdasarkan waktu, tenaga serta biaya yang terbatas. Tempat penelitian yaitu 3 SMA Negeri di Bondowoso yaitu SMAN 1 Tenggarang, SMAN 1 Tapen, dan SMAN 3 Bondowoso. Subjek penelitian adalah 1 kelas siswa kelas $\mathrm{X}$ di masing-masing sekolah yang menjadi tempat penelitian. Penelitian dilaksanakan pada semester ganjil tahun ajaran 2020/2021. Instrumen dalam penelitian ini adalah tes yang bertujuan untuk mendeskripsikan kemampuan multirepresentasi siswa yaitu kemampuan representasi gambar, dan representasi matematis.

Tahapan penelitian ini meliputi: (1) tahap pendahuluan, yaitu menentukan tempat dan subjek penelitian, (2) tahap pembuatan instrumen penelitian berupa tes kemampuan multirepresentasi, (3) tahap pengumupulan data dengan melakukan tes kemampuan multirepresentasi kepada siswa, (4) tahap analisis data yaitu dengan mengakumulasikan hasil tes siswa yang kemudian digunakan untuk mengetahui kemampuan multirepresentasi siswa pada pokok bahasan gerak lurus, dan (5) tahap penarikan kesimpulan yang diperoleh berdasarkan hasil analisis data yang telah didapatkan.

Teknik pengumpulan data dalam penelitian ini meliputi: (a) Tes, tes yang dilakukan dalam penelitian ini berguna untuk mengetahui kemampuan multirepresentasi yaitu representasi gambar dan representasi matematis. Hasil tes yang dilakukan digunakan sebagai tolak ukur kemampuan multirepresentasi siswa dengan cara mendeskripsikan data yang diperoleh. Soal yang digunakan dalam tes adalah modifikasi dari soal Ujian Nasional serta soal SBMPTN tahun-tahun sebelumnya, (b) wawancara, digunakan sebagai data pendukung pembahasan yang berasal dari siswa yang mengikuti tes, dan (c) dokumentasi berupa absensi siswa, nilai siswa sebagai data pendukung pembahasan. Instrumen yang digunakan adalah instrumen tes sejumlah 5 soal. Masing-masing soal mengandung pertanyaan representasi yaitu representasi gambar dan representasi matematis. Teknik analisis data penelitian ini adalah analisis deskriptif. Analisis deskriptif kuantitatif merupakan analisis yang digunkan sebagai teknik pengolahan data hasil tes sehingga didapatkan nilai kemampuan multirepresentasi siswa berupa representasi gambar dan representasi matematis. Analisis data kualitatif berfungsi sebagai penerjemah data kuantitatif dengan memberikan kategori kemampuan multirepresentasi siswa berdasarkan skor tes yang dilakukan. Kemudian dilakukan analisis berdasarkan indikator yang telah ditentukan.

Analisis kemampuan multirepresentasi siswa berupa representasi gambar dan representasi matematis menggunakan suatu rumusan. Kemudian analisis data dilakukan dengan menghitung persentase nilai kemampuan multirepresentasi per indikator dengan rumus berikut.

$\%=\frac{\sum n}{\sum N} \times 100$

Keterangan:

$\mathrm{N}$ : jumlah skor yang diperoleh siswa

$\mathrm{N}$ : jumlah skor maksimum siswa

$\%$ : persentase kemampuan menyelesaikan masalah

Hasil perhitungan menggunakan rumus tersebut dapat menentukan kategori tingkat 
kemampuan menyelesaikan masalah seperti Tabel 1 berikut.

Tabel 1. Kategori Kemampuan Multirepresentasi

\begin{tabular}{ll}
\hline Kategori & Persentase $(\%)$ \\
\hline Baik Sekali & $81-100$ \\
\hline Baik & $61-80$ \\
\hline Cukup & $41-60$ \\
\hline Kurang & $21-40$ \\
\hline Sangat Kurang & $0-20$
\end{tabular}

(Purwanto, 2010)

Langkah berikutnya adalah penyajian data. Data yang telah dilakukan analisis disajikan dalam bentuk tabel. Kemudian dilakukan interprestasi data yaitu proses pemahaman makna berdasarkan data yang tersaji menggunakan tafsiran atau penjabaran dari data yang disajikan. Kemudian yang terakhir dilakukan penarikan kesimpulan.

\section{HASIL DAN PEMBAHASAN}

Instrumen penelitian berupa tes yang berjumlah 5 soal uraian dimana masingmasing soal mengandung soal representasi. Penelitian dilakukan di SMAN 1 Tenggarang, SMAN 1 Tapen, dan SMAN 3 Bondowoso. Penelitian dilakukan untuk mengetahui kemampuan multirepresentasi berupa representasi gambar dan representasi matematis.

Materi yang digunakan dalam penelitian ini adalah materi gerak lurus. Materi gerak lurus terdapat pada kelas X semester ganjil. Materi gerak lurus memerlukan tingkat pemahaman konsep yang tinggi karena beberapa materi pada materi gerak lurus bersifat abstrak. Materi gerak lurus terdapat pada semester ganjil tahun ajaran 2020/2021.

Data penelitian diperoleh dari hasil tes yang dilakukan. Setelah tes dilakukan kemudian dilakukan analisis pada masingmasing representasi. Data tersebut kemudian digunakan untuk mengukur tingkat kemampuan representasi gambar dan representasi matematis.

Kemampuan multirepresentasi berdasarkan indikator ditunjukkan pada Tabel 2 berikut.

Tabel 2. Persentase Kemampuan $\begin{array}{llll}\text { Multirepresentasi siswa } & \text { SMAN } 1\end{array}$ Tenggarang

\begin{tabular}{lll}
\hline Keterangan & $\begin{array}{l}\text { Persentase } \\
\text { Indikator }\end{array}$ & per \\
\cline { 2 - 3 } & A & B \\
\hline Baik Sekali & 83,3 & 86,1 \\
\hline Baik & 13,9 & 11,1 \\
\hline Cukup & 2,8 & 2,8 \\
\hline Kurang & 0.0 & 0.0 \\
\hline Sangat Kurang & 0.0 & 0.0 \\
\hline
\end{tabular}

Keterangan :

A : indikator representasi gambar

$\mathrm{B}$ : indikator representasi matematis

Berdasarkan Tabel 2 tampak pada indikator pertama yaitu representasi gambar siswa SMAN 1 Tenggarang materi gerak lurus berkategori baik sekali. Hal tersebut terlihat pada kategori baik sekali yang bernilai 83,3 persen, pada kategori baik bernilai 13,9 persen, dan kategori cukup 2,8 persen. Siswa cenderung mengalami kesulitan untuk membayangkan dan memberikan gambar terhadap ilustrasi yang dimaksudkan dalam kasus materi gerak lurus. Siswa kesulitan dalam menggambarkan ilustrasi pada fenomena fisika yang terjadi dalam materi gerak lurus. Siswa merasa asing dengan soal yang berbasis representasi gambar, karena dalam pembelajaran fisika biasanya siswa hanya ditekankan pada aspek representasi matematis saja. Menurut Ella dalam (Kartini, 2009) penggunaan representasi dapat memberikan dampak positif untuk memecahkan permasalahan fisika. Berdasarkan hal tersebut sebaiknya guru mempertimbangkan cara mengajar dengan menggunakan seluruh kemampuan 
representasi jangan hanya menggunakan salah satunya saja.

Indikator kedua adalah representasi matematis. Berdasarkan Tabel 2 representasi matematis siswa SMAN 1 Tenggarang materi gerak lurus berkategori baik sekali. Sebesar 86,1 persen pada kategori baik sekali, 11,1 persen pada kategori baik, dan 2,8 persen pada kategori cukup. Siswa SMAN 1 tenggarang tidak ada yang memperoleh kategori kurang dan sangat kurang pada indikator representasi matematis.

Berdasarkan penelitian yang telah dilakukan kendala siswa dalam mengerjakan soal berbasis representasi matematis adalah dipengaruhi oleh sulitnya siswa dalam mengidentifikasi soal yang diberikan. Menurut Dahlan dan Juandi (2011:134) siswa telah memiliki kemampuan yang cukup baik untuk memecahkan permasalahan fisika dengan menggunakan representasi matematis. Kebiasaan siswa saat mengerjakan soal hanya bergantung pada kemampuan menghafal rumus saja tanpa memahami persoalan yang diberikan. Hal tersebut berpengaruh pada susahnya menemuka strategi yang tepat dalam mengerjakan soal representasi matematis. Namun juga ada beberapa siswa yang sudah mampu mengidentifikasi persoalan sehingga hasil akhir yang diperoleh sudah benar. Sehingga dapat dikatakan bahwa kendala utama yang dihadapi siswa adalah kecenderungan menghafal rumus tanpa memikirkan cara tepat untuk menyelesaikan persoalan karena kurangnya pemahaman konsep fisika.

Berdasarkan kedua aspek representasi diatas maka dikatakan bahwa kemampuan multirepresentasi siswa SMAN 1 Tenggarang berkategori baik. Namun, proses pembelajaran masih perlu diadakan pembenahan dari cara belajar siswa ataupun dari cari mengajar guru. Guru sebaiknya memiliih metode mengajar yang tepat agar dapat meningkatkan kemampuan multirepresentasi siswa. Data yang diperoleh juga sebagai introkpeksi peneliti agar dapat dijadikan bekal saat mengajar nanti. Karena sejatinya soal-soal fisika tidak hanya mengandung representasi matematis saja melainkan mengandung representasi gambar, verbal, dan grafik juga yang saling berhubungan satu sama lainnya.

Tabel 3. Persentase Kemampuan Multirepresentasi siswa SMAN 1 Tapen

\begin{tabular}{lll}
\hline Kriteria & $\begin{array}{l}\text { Persentase tiap Indikator } \\
(\%)\end{array}$ \\
\cline { 2 - 3 } & $\mathrm{A}$ & $\mathrm{B}$ \\
\hline Baik Sekali & 88,0 & 68,0 \\
\hline Baik & 0.0 & 20,0 \\
\hline Cukup & 12,0 & 12,0 \\
\hline Kurang & 0.0 & 0.0 \\
\hline Sangat Kurang & 0.0 & 0.0 \\
\hline
\end{tabular}

Keterangan :

A : indikator representasi gambar

$\mathrm{B}$ : indikator representasi matematis

Berdasarkan Tabel 3 tampak pada indikator pertama yaitu representasi gambar siswa SMAN 1 Tapen materi gerak lurus berkategori baik sekali. Hal tersebut terlihat pada kategori baik sekali yang bernilai 88,0 persen, dan pada kategori cukup 12,0 persen. Siswa yang kesulitan mengerjakan soal berbasis representasi gambar mengaku kesulitan untuk membayangkan dan menggambarkan ilustrasi pada soal yang ada dalam kasus materi gerak lurus. Siswa juga tidak terbiasa menggambarkan ilustrasi pada fenomena fisika khususnya yang terjadi dalam materi gerak lurus. Siswa tidak terbiasa mengerjakan soal yang berbasis representasi gambar, karena dalam pembelajaran siswa hanya diajarkan dengan menggunakan representasi matematis saja. Menurut Selamet dkk (2018:147) mengatakan bahwa kesulitan siswa dalam menguasai kemampuan representasi gambar 
diakibatkan oleh siswa yang kurang familiar dengan soal yang berbasis representasi gambar. Berdasarkan hal tersebut sebaiknya menjadi pertimbangan guru untuk memperbaiki metode pembelajaran yang digunakan yaitu dengan menggunakan seluruh kemampuan representasi. Karena sejatinya seluruh kemampuan representasi itu saling beruhubungan satu sama lain, sehingga tidak bisa hanya digunakan salah satunya saja.

Indikator kedua adalah representasi matematis. Berdasarkan Tabel 3 representasi matematis siswa SMAN 1 Tapen materi gerak lurus berkategori baik sekali. Sebesar $68,0 \%$ pada kategori baik sekali, 20,0 \% pada kategori baik, dan $12,0 \%$ pada kategori cukup. Siswa SMAN 1 Tapen tidak ada yang memperoleh kategori kurang dan sangat kurang pada indikator representasi matematis. Hal tersebut selaras dengan penelitian Kurniasari dan Wasis (2021:147) mengatakan bahwa kemampuan representasi matematis siwa sangat kuat, akan tetapi fisika bukanlah mata pelajaran yang hanya memfokuskan pada satu kemampuan representasi saja. Berdasarkan hasil penelitian, kendala yang dialami siswa dalam pada soal berbasis representasi matematis dipengaruhi oleh kesulitan siswa dalam mengidentifikasi maksud dari soal yang diberikan. Siswa biasanya mengerjakan soal hanya dengan mengandalkan hafalan rumus saja tanpa mencoba memahami konsep pada persoalan yang diberikan. Hal tersebut tentu mempengaruhi proses mengerjakan soal representasi matematis. Namun, ada beberapa siswa yang mampu mengidentifikasi persoalan dengan baik. Sehingga kendala utama siswa adalah kebiasaan hanya menghafal rumus tanpa memikirkan strategi peyelesaian soal yang disebabkan karena kurangnya pemahaman konsep fisika.

Berdasarkan keseluruhan aspek representasi, maka dapat dikatakan bahwa kemampuan multirepresentasi siswa SMAN 1 Tapen berkategori baik. Namun, dengan kategori tersebut masih saja diperlukan suatu perbaikan serta peningkatan kualitas pembalajaran khususnya pada proses pembelajaran yang masih perlu diadakan pembenahan dari berbagai sisi. Salah satunya bagi guru sebaiknya menggunakan metode mengajar yang baik agar mampu meningkatkan kemampuan multirepresentasi siswa baik reprsentasi gambar dan matematis. Data penelitian yang diperoleh juga dapat dijadikan sebagai introkpeksi peneliti supaya dijadikan bekal saat terjun ke lapangan nanti.

Tabel 4. Persentase Kemampuan Multirepresentasi siswa SMAN 3 Bondowoso

\begin{tabular}{lll}
\hline \multirow{2}{*}{ Keterangan } & \multicolumn{2}{l}{ Persentase per Indikator } \\
\cline { 2 - 3 } & $\mathrm{A}$ & $\mathrm{B}$ \\
\hline Baik Sekali & 96,5 & 86,2 \\
\hline Baik & 3,5 & 10,3 \\
\hline Cukup & 0.0 & 3,5 \\
\hline Kurang & 0.0 & 0.0 \\
\hline Sangat Kurang & 0.0 & 0.0 \\
\hline
\end{tabular}

Keterangan :

A : indikator representasi gambar

$\mathrm{B}$ : indikator representasi matematis

Berdasarkan Tabel 4 tampak pada indikator pertama yaitu representasi gambar siswa SMAN 3 Bondowoso materi gerak lurus berkategori baik sekali. Hal tersebut tampak pada kategori baik sekali yang bernilai 96,5 persen, dan pada kategori baik 3,5 persen. Siswa di SMAN 3 Bondowoso cukup pandai dalam hal membayangkan ilustrasi dan menggambarkan ilustrasi kasus pada soal yang ada dalam materi gerak lurus. Siswa juga tidak terbiasa mengerjakan soal yang mengharuskan menggambarkan ilustrasi fenomena fisika. Siswa masih asing untuk mengerjakan soal yang berbasis representasi gambar, karena dalam pembelajaran fisika siswa sering diajarkan hanya dengan menggunakan representasi 
matematis. Menurut Kurniasari dan Wasis (2021:147) mengatakan bahwa hal tersebut terjadi akibat adanya kecenderungan guru yang memberi pembelajaran hanya mengandalkan satu representasi saja sehingga siswa tidak cakap menggunakan representasi yang lainnya. Mempertimbangkan hal tersebut sebaiknya menjadi pertimbangan guru agar memperbaiki metode pembelajaran yang digunakan. Sejatinya seluruh kemampuan representasi itu berhubungan satu sama lain, sehingga pada saat digunakan tidak bisa dipisahkan.

Indikator kedua adalah representasi matematis. Berdasarkan Tabel 4 representasi matematis siswa SMAN 3 Bondowoso materi gerak lurus berkategori baik sekali. Sebesar 86,2 \% pada kategori baik sekali, dan 10,3 \% pada kategori baik. Siswa SMAN 3 Bondowoso mengalami kendala dalam mengerjakan soal berbasis representasi matematis yang diakibatkan karena kesulitan siswa dalam mendefinisikan maksud dari soal yang diberikan. Menurut Selamet dkk (2018:147) kendala yang dialami siswa dalam representasi matematis adalah karena siswa yang kurang terampil dalam menggunakan persamaan matematis sehingga siswa kadang keliru menggunakan persamaan yang tepat sesuai dengan soal. Siswa biasanya mengerjakan soal hanya dengan mengandalkan hafalan rumus saja, sedangkan dalam soal memerlukan pemahaman mendalam untuk mengerjakan soal yang diberikan. Hal tersebut sangat mempengaruhi proses mengerjakan soal representasi matematis. Namun masih ada beberapa siswa yang mampu mengidentifikasi makna soal dengan baik.

Berdasarkan keseluruhan aspek representasi maka dapat dikatakan bahwa kemampuan multirepresentasi siswa SMAN 3 Bondowoso berkategori cukup. Berdasarkan kategori tersebut, maka sangat diperlukan perbaikan serta peningkatan kualitas pembelajaran. Salah satunya bagi guru sebaiknya memilih menggunakan metode mengajar yang tepat agar mampu meningkatkan kemampuan multirepresentasi siswa baik reprsentasi gambar dan matematis.

\section{SIMPULAN DAN SARAN}

Kemampuan representasi gambar dan matematis siswa SMAN 1 Tenggarang berkategori baik sekali dengan persentase sebesar $91,1 \%$ dan 91,7\%, kemampuan representasi gambar dan matematis siswa SMAN 1 Tapen berkategori baik sekali dengan persentase sebesar 95,2\% dan $81,9 \%$, dan kemampuan representasi gambar dan matematis siswa SMAN 3 Bondowoso berkategori baik sekali dengan persentase sebesar 99,3\% dan 88,3\%. Adapun saran untuk penelitian ini yaitu agar guru yang bersangkutan untuk melakukan tindak lanjut untuk memperbaiki metode pembelajaran yang digunakan untuk meningkatkan kemampuan multirepresentasi siswa.

\section{DAFTAR PUSTAKA}

Alexandru Maries., Shih Yin Lin., dan Chandralekha Singh. 2017. Challenges In Designing Appropriate Scaffolding To Improve Studentse Representational Consistency: The Case Of A Gausse's Law Problemee. Physical Review Physics Education Research. 13(2):1.

Apriliyani, A. 2019. Perbedaan Kemampuan Multi Representasi Fisika Peserta Didik Menggunakan Metode Hypnoteaching Dengan Think Aloud Pair Problem Solving (TAPPS) Pada Materi Gerak Melingkar. Disertasi. Lampung: Program Pasca Sarjana Universitas Islam Negeri Raden Intan Lampung. 
Arifah, K., Indrawatiningsih, N., dan Afifah, A. 2020. Analisis Kemampuan Multiple Representasi Siswa dalam Memecahkan Masalah Peluang. JP2M (Jurnal Pendidikan dan Pembelajaran Matematika). 6(2):67-76.

Dahlan, J. A., dan Juandi, D. 2011. Analisis Representasi Matematik Siswa Sekolah Dasar dalam Penyelesaian Masalah Matematika Kontekstual. Jurnal Pengajaran MIPA. 16(1), 128138.

Doyan, A., Taufik, M., dan Anjani, R. 2018. Pengaruh pendekatan multi representasi terhadap hasil belajar fisika ditinjau dari motivasi belajar peserta didik. Jurnal Penelitian Pendidikan IPA. 4(1).

Dudeliany, J. A., Mahardika, I. K., dan Maryani, M. 2021. Penerapan Model Pembelajaran Berbasis Masalah (PBM) disertai LKS Berbasis Multirepresentasi pada Pembelajaran IPA-Fisika Di SMP. Jurnal Pembelajaran Fisika. 3(3):254-259.

Handiyanti, D.R., Mahardika, I.K., dan Astutik, S. 2019. Efektivitas Model PBL Berbantuan Simulasi Phet untuk Meningkatkan Kemampuan Representasi Matematik Siswa SMA. FKIP e-PROCEEDING, 3(2):119124.

Harahap, Ria A dan Derlina D. 2017. Pembelajaran Kooperatif Tipe Group Investigation (GI) Dengan Metode Know-Want-Learn (KWL): Dampak Terhadap Hasil Belajar Fluida Dinamis. Jurnal Ilmiah Pendidikan Fisika Al-Biruni. 6(2):150.

Kartini, K. 2009. Peranan representasi dalam pembelajaran matematika. In Seminar Nasional Matematika Dan Pendidikan Matematika.

Kurniasari, L. Y., dan Wasis, W. 2021. Analisis Kemampuan Multi Representasi dan Kaitannya dengan
Pemahaman Konsep Fisika. Jurnal Pijar MIPA. 16(2): 42-150.

Mahardika, I. K. 2016. Penggunaan Pendekatan Multirepresentasi dengan Setting Quantum Teaching dalam Pembelajaran Gerak Melingkar dan Dampaknya Terhadap Pemahaman Konsep Mahasiswa Calon Guru Fisika. Jurnal Pembelajaran Fisika. 4(5):545-554.

Mahendra, N. R., Mulyono, M., \& Isnarto, I. 2019. Kemampuan Representasi Matematis dalam Model Pembelajaran Somatic, Auditory, Visualization, Intellectually (SAVI). In PRISMA, Prosiding Seminar Nasional Matematika (Vol. 2, pp. 287-292).

Najib, K., Siswanto, J., dan Saefan, J. 2020. Pengaruh Pendekatan Multirepresentasi terhadap Kemampuan Kognitif Siswa dalam Pembelajaran Fisika. Journal of Banua Science Education. 1(1).

Selamet, S., Mahardika, I. K., dan Supriadi, B. 2018. Analisis Kemampuan Representasi Verbal, Matematika, Gambar dan Grafik (R-VMMG) Siswa SMAN Pasirian pada Materi Termodinamika. FKIP e-Proceeding. 3(1):144-148.

Yuniarti, Y. 2016. Peran Guru dalam Meningkatkan Kemampuan Representasi Matematika dalam Pembelajaran Matematika. EduHumaniora Jurnal Pendidikan Dasar Kampus Cibiru. 5(1). 